\title{
A experiência do telejornal: âncora naturalista
}

\section{RESUMO}

Este artigo reflete sobre aspectos estéticos da televisão e, em especial, do telejornal brasileiro. Partindo da discussão sobre um predomínio ou não de uma estética naturalista, o artigo considera as transformações que ocorrem na relação mundo/tevê/espectador para inquirir sobre o real narrado pelos telejornais.

\section{PALAVRAS-CHAVE \\ televisão \\ telejornal \\ experiência.}

\begin{abstract}
This article reflects upon aesthetic aspects of television and, in special, of the Brazilian television news. Focusing on the debate about the predominance or not of "realism", the article considers the transformations that occur in the relation world/ telly/viewer in order to inquire about the real represented by the television news
\end{abstract}

\section{KEY WORDS}

television

news

experience

\author{
Bruno Souza Leal \\ Professor do Programa de Pós-Graduação em Comunicação Social/UFMG/ \\ MG/BR \\ brunosl@uol.com.br
}

Os estudos sobre televisão, tal como observa FAHLE (2006), raramente consideram seus aspectos estéticos, privilegiando análises das condições de produção, de recepção, de aspectos político-ideológicos, entre outros. A ausência de um maior volume de reflexões sobre a experiência estética televisual em parte é explicada pelo desprezo freqüente com que a tv é vista, uma vez que ela é a face mais visível da indústria cultural, uma vez que ela se apresenta como informação ou entretenimento e quase nunca como "arte". No entanto, já na década de 60, Umberto Eco, em sua Obra Aberta ${ }^{1}$, havia postulado uma estética televisual, a partir do esforço de compreensão das transmissões ao vivo. Naquele momento, Eco reconhecia a tevê como uma "experiência", como realização e completamento, mesmo na dispersão de fatos e situações do cotidiano. Menos, portanto, que a experiência forte de John Dewey, Eco viu na narrativa do "ao vivo" da tv uma experiência na amplitude do termo: como experimentação, como experimento, como realização, como vivência.

$\mathrm{Na}$ configuração de uma estética televisual, Eco cunha o termo "mimese da experiências" como forma de alcançar os níveis ou dimensões que a constituem. Afinal, a tv tenta "adivinhar" e incorporar em seus "textos" experiências alheias - dos eventos a serem narrados e dos espectadores - o que constitui sua própria experiência de interpretação e mimese (ECO, 2003,pp187/188.). Assim, fica claro que uma estética televisual se constitui nos modos como os eventos do mundo são interpretados, reorganizados e ofertados via linguagem ao telespectador, num processo em que, para Eco, a tv realiza uma espécie de dupla "poiesis": a narrativa televisual seria resultado de uma experiência de mediação e ao mesmo tempo produziria uma experiência do mundo, na sua relação com o espectador.

Chama a atenção nessas reflexões iniciais de Eco o destaque dado por ele à verossimilhança, tido como um dos elementos estéticos fundamentais da transmissão ao vivo. Aliás, é na constituição da verossimilhança que a expressão "mimese de experiências" 2 parece adquirir contornos mais definidos. Diante da casualidade dos acontecimentos cotidianos, a tv tem que elaborar uma narrativa com nexos bem constituídos, para que o telespectador reconheça não só do que se trata mas a própria narrativa e sua legitimidade. Instaura-se ai um jogo de interpretação e antecipação: a leitura do mundo feita pela tv seria condicionada pelo esforço de antecipar as expectativas dos espectadores. Com isso, observa Eco, o hábito e o habitual se tornam fundamentais e levam à verossimilhança: “...O primeiro tipo de nexo que se apresenta como psicologicamente mais fácil e imediato é o 
que se fundamenta no hábito, o hábito do verossímil segundo a opinião corrente.". Assim, "[o] único nexo possível que sua [do diretor de tv] educação..... Ihe permite é aquele estabelecido pela convenção de verossimilhança, e, portanto, a única solução sintática possível é a correlação segundo a verossimilhança tradicional" (ECO, 2003, p.198). A "mimese de experiências" da tevê, portanto, vincula-se ao esforço de constituição de uma narrativa verossímil, a partir da reprodução dos nexos habituais e correntes, a princípio compartilhados entre os que fazem e os que assistem à tevê.

\section{De acordo com Flora Sussekind (1984), no Brasil, no Dezenove, o realismo tem um dos seus pontos altos na escola naturalista, que seria o ponto de partida para uma tradição estético-ideológica que se prolongaria, num eterno retorno, no século seguinte.}

Como se sabe, verossimilhança é um termo-chave de qualquer estética realista e ao ressaltar sua importância na televisão, Eco tanto oferece pistas sugestivas para a apreensão da experiência televisual como dá início a uma polêmica: sobre o predomínio ou não de uma padrão realista/naturalista na tevê. Essa polêmica adquire contornos vários, mas surge especialmente na contraposição com o cinema, como apontou Pucci Jr.(2005). O autor observa que, em diferentes tratamentos, a tevê surge tanto como o meio fundamentalmente "antinaturalista" quanto como de um "naturalismo" contagioso. Em ambos os casos, o contraponto, segundo Pucci Jr, é uma concepção de cinema que se quer valorizar. Em outras palavras, se "cinema" é representação da realidade, a tevê é incapaz desse feito; se o cinema é invenção, a tevê é naturalista. Na revisão crítica da (in)distinção entre cinema e tevê, Pucci Jr, afirma que a polêmica associa-se ao esforço de caracterizar a essência ou a pureza da cada meio, o que, sob o seu olhar, seria uma falácia, na qual o naturalismo é apenas um dos pomos da discórdia. Nesse sentido, ainda que o termo "naturalismo" abranja recursos e procedimentos, Pucci Jr. o define como sinônimo de realismo, ou seja, como a "...semelhança entre aquilo a que se assiste e o que o senso comum supõe ser o mundo real" (2005, p.186).

Diante desse quadro, o realismo na tevê adquire grande complexidade, pois oscila entre a caracterização de certos procedimentos e peculiaridades de gêneros e formatos televisuais e uma possível identidade estética própria do meio. Nesse sentido, é extremamente significativa a contradição apontada - e da qual ele parece não escapar - por Robert Stam(1985), quando observa a relação do telejornal e seu espectador. Para Stam, se os telejornais tem um freqüente uso de procedimentos naturalistas, seria possível encontrar neles certos recursos tipicamente antiilusionistas ou, nos seus termos, "brechtianos". Assim, para Stam, seria um "equivoco" dizer que o telejornal é fundamentalmente naturalista, pois, por um lado, "a continuidade ilusionista é simplesmente impraticável" e a "crença" do telespectador depende menos de procedimentos naturalistas que de um pacto maior, o compromisso do jornalismo com eventos que "realmente" acontecem. Por outro lado,

Muitos dos elementos de distanciamento caracterizados como brechtianos nos filmes de Godard são igualmente típicos da televisão: a designação do aparelho de base; a copresença de imagens múltiplas dentro do contorno do vídeo; a inclusão de materiais bidimensionais; o discurso direto para o espectador; as 'interrupções' comerciais do fluxo narrativo; a justaposição de fatias heterogêneas de discurso; a mistura de modelos documentais e ficcionais; a subversão de uma hegemonia visual através do predominio de uma trilha sonora; a busca constante de apoio no material escrito; a incorporação criativa dos erros (STAM, 1985,p.85)

Stam identifica assim no telejornal a contradição de trazer elementos tanto naturalistas quanto antiilusionistas. No entanto, Stam parece mesmo se contradizer ao alertar que o brechtianismo televisivo é "ambíguo" e "aviltado", dado que os "mecanismos de distanciamento" no telejornal, "...são, se não naturalistas, pelo menos antibrechtianos" (1985, p.85). Observa-se, então, que Stam não se preocupa apenas em dizer se a tevê, ou um dos seus produtos, o telejornal, adota procedimentos naturalistas, mas de caracterizar algo que lhe é fundamental. É na identificação dessa natureza do meio ou de um mesmo de um dos seus produtos que a contradição se instala, pois advém de um olhar homogeneizador. Além disso, fica claro que para Stam o termo "naturalismo" nomeia um conjunto de procedimentos que visam à ilusão referencial, ao "efeito de real", e portanto se opõe a todos os demais procedimentos "antiilusionistas". Com isso, é possível objetar que ainda que um certo conjunto de procedimentos tenha se constituição nas tradições literária e visual do Ocidente, nenhum recurso de linguagem tem valor em si mesmo e que uma mesma estratégia pode ser "ilusionista" num texto e rechaçar essa ilusão em outro. Assim, por exemplo, "a designação do aparelho de base" pode servir igualmente ao efeito de distanciamento em alguns filmes de Godard e à autenti- 
cação de reportagem como relato legítimo do real.

Se não se pode reivindicar que uma estratégia seja essencialmente ilusionista ou não, por outro lado, uma concepção ampla de naturalismo, tal como utilizada por Pucci Jr., apaga a própria complexidade do fenômeno histórico a que se refere. Afinal, nem todo realismo é naturalista, e se pelo menos desde o século XIX esses termos designam correntes estéticas próximas, a ponto de serem encontrados frequentemente juntos, seu fôlego e impacto variam nos diferentes contextos culturais nos quais surgem. Assim, menos que responder se a tevê seria ou não fundamentalmente realista, convém perguntar por que um telejornal, por exemplo, precisa ou escolhe assim o ser. Afinal, parece ser ponto pacífico que, de fato, como Eco havia apontado, há um esforço grande de verossimilhança nas narrativas televisuais. Perguntase, então, que verossimilhança é essa, a que ela responde, que real produz. A resposta indica menos uma natureza do meio, mas uma "estética" e talvez uma pragmática da tevê e telejornalismo brasileiro, hoje. É o que se propõe este artigo, que tem como foco não toda a tevê brasileira, mas um dos seus produtos paradigmáticos, o telejornal

\section{A cartola naturalista no Brasil}

Para Hans Gumbrecht (2004), o realismo, em suas diversas formas, foi uma das tentativas desenvolvidas, a partir do séc.XIX, de apropriação do mundo, de realidades cada vez mais "multiperspectivas" . Ou seja, uma das "incessantes tentativas, algumas vezes violentas, mas nunca bem sucedidas, de unificar percepção e experiência”. Afinal, os discursos narrativos “...abrem um espaço no qual a multiplicidade de representações podem ser integradas e moldadas em uma seqüência" (2004,p.40, no original em inglês).

De acordo com Flora Sussekind (1984), no Brasil, no Dezenove, o realismo tem um dos seus pontos altos na escola naturalista, que seria o ponto de partida para uma tradição estético-ideológica que se prolongaria, num eterno retorno, no século seguinte. ${ }^{3}$ Como salienta a autora, apresentando-se como escrita do real, o naturalismo pressupõe uma linguagem transparente, invisível, capaz de deixar ver o "mundo", a "história", a "verda$\mathrm{de}^{\prime \prime}$. Menos que um conjunto de procedimentos, o naturalismo e os outros realismos seriam "ideologias estéticas" que surgiram no Ocidente no bojo de transformações sociais e econômicas.

Assim, os realismos surgem como esforços estéticos e ideológicos de unificação de realidades fragmentadas, lançando mão, para isso, do estabelecimento de nexos causais, por exemplo entre o homem e o meio ou as transformações econômicas. Analisando três momentos dessa tradição no Brasil (do final do séc. XIX ao final do séc.XX, passando pelo romance regionalista de 30), Sussekind conclui que

A moldura naturalista é estreita. Nela não cabem fragmentos. Nela não há lugar para dúvidas ou divisões. A imagem naturalista reconstitui com minúcia microscópica uma identidade fraturada e tenta revigorar seios-enfraquecidos de uma AméricaIracema que procura repetidamente, senão reviver, ao menos retratar. Sob a forma de estudos de temperamento, dos ciclos, dos romances-reportagem. E com o auxílio de lentes tomadas de empréstimo ora à ciência natural, ora às ciências sociais, ora às ciências da comunicação. Lentes meio mágicas que tiram do fundo falso de uma cartola estético-ideológica identidades que não se possuem, e as trilhas de uma viagem impossível em direção à utopia.(1984, p.198)

\section{Ao caracterizar o romance- reportagem como naturalista, Sussekind dá ênfase ao "projeto ideológico" que o orienta, 0 de dar coerência e coesão, via} narrativa, a uma suposta realidade nacional, emudecida pela ditadura.

É significativo, nesse sentido, lembrar que Sussekind identifica como um terceiro momento do naturalismo no Brasil os romances-reportagens dos anos 70, quando romancistas como José Louzeiro e Aguinaldo Silva se impuseram a tarefa de falar/revelar do Brasil diante da censura militar. Para tal, elegeram o jornalismo como principal referência, baseando-se numa suposta identidade entre jornalistas e leitores. Explica Sussekind:

Como nos naturalismos do século passado e dos anos Trinta, também na década de setenta a produção romanesca se faz em analogia com um saber privilegiado. Não é a biologia. Não é a economia(...).Quem tem voz é o jornalista e o modelo de romance é a reportagem. Até o país passa a ter por imago uma redação de jornal. Onde se lê jornal, leia-se Brasil. Onde se lê repórter, leia-se sociedade brasileira (1984, pp.179/180).

Esse laço ideológico e estético que une jornalistas e leitores gera um "nós", um lugar comum habitado por todos que teria o nome de Brasil ou sociedade brasileira. Afinal, caberia ao repórter, seja ele o autor ou mesmo uma personagem ficcional, apresentar a realidade do 
país a todos, trazendo à tona o "nosso mundo" ${ }^{4}$. Ao escolher narrar casos, mesmo via metáfora, como os de Ângela Diniz ou Cláudia Lessin, o romance-reportagem apresenta o que Sussekind entende ser uma principal estratégia, a singularização. Através de Lúcio Flávio, por exemplo, faz-se um "retrato 2 X2 da sociedade brasileira" (1984,p.182), Essa singularização se torna "naturalista", segundo a autora, ao se voltar à produção de ilusão referencial, servindo tanto para autenticar o relato, quanto o jornalista e a própria imprensa. Nesse sentido, Sussekind observa em nota que "não é de estranhar" que "...tal procedimento estético tenha sido assimilado com tanta facilidade por um veículo como a televisão" (1984, p.182n).

Antes da tevê, porém, é importante observar que não é de se estranhar, da mesma forma, que o jornalismo tenha sido a fonte de inspiração do romance-reportagem. Como nota a pesquisadora portuguesa Cristina Ponte, .o jornalismo que se desenvolve no Ocidente a partir do século XIX, voltado para o relato dos fatos atuais, “... vai encontrar no realismo algumas de suas metáforas fundadoras, como a de 'espelho da vida', proposta por Stendhal, ou sua matéria-prima, os acontecimentos, como mimeses dos seres e das coisas..." (2005, p.45)

Contemporâneo do realismo europeu de Balzac e Zola, entre outros, o jornalismo de fatos e notícias se opõe ao jornalismo panfletário como aqueles autores se opunham às idealizações românticas. Como narrativas do real, a literatura ficcional realista e e as notícias chegam a compartilhar procedimentos narrativos, como a ênfase na descrição, no diálogo e com o auxílio dos "pormenores insignificantes" identificados por Barthes. Ainda que por vez esquecida - até mesmo pelo esforço de se distinguirem - a relação jornalismo/literatura realista por vezes emerge claramente, como no "Novo Jornalismo" de Tom Wolfe e outros, que até hoje serve de parâmetro nas redações brasileiras. Em alguns dos seus artigos sobre o "Novo Jornalismo", Wolfe (2005) utiliza a expressão como sinônimo de "Novo Realismo", ao mesmo tempo criticando e deixando claro que o - suposto abandono do realismo pelos escritores ficcionais ("neofabulistas") abriu caminho para que os jornalistas desenvolvessem um tipo de reportagem que melhor refletiria a sociedade americana dos anos 60 em diante.

Realista desde seu nascimento, portanto, o jornalismo permanece a ele vinculado, apesar das diversas transformações pelas quais passou ao longo dos séculos seguintes. Nesse sentido, Cristina Ponte é bastante precisa: "Mais de um século depois do aparecimento desta escrita jornalística, será esta ilusão de realidade menos consciente no jornalismo que nas palavras de Maupassant? Também podemos nos interrogar por que continuam a circular as metáforas do jornalismo como espelho da realidade, seu reflexo sem limites nem pressões..." (2005, p.50)

Ao caracterizar o romance-reportagem como natura- lista, Sussekind dá ênfase ao "projeto ideológico" que o orienta, o de dar coerência e coesão, via narrativa, a uma suposta realidade nacional, emudecida pela ditadura. Há, portanto, dois pressupostos fundamentais que caracterizam qualquer estética realista e que são possíveis de identificar no jornalismo: a existência de uma realidade, de uma verdade do mundo a ser desvendada/ narrada, e a natureza da linguagem como meio, cuja função seria dar transparência ao real.

\section{Os apresentadores e espectadores convidados que aparecem no vídeo funcionam como espécies de alter ego do espectador que está em casa, com os quais este identifica e se relaciona.}

A "cartola" estética-ideológica do realismo/naturalismo, portanto, estaria integrada a um "chão" epistemológico que não só define um ser da linguagem, mas que estabelece condições para que sejam interpretadas as representações do mundo, baseadas na descontinuidade entre sujeito/objeto, mente/corpo, sentido/sensível. Como bem salientou Sussekind, a adoção do realismo propõe uma experiência cuja dimensão ideológica dessa estética é facilmente alcançada quando se verifica qual real seria alvo dessa mímesis: uma realidade nacional, una,indivisível. Para Sussekind, a estética naturalista no Brasil, apoiada na ideologia da objetividade da ciência e do jornalismo, constituiria mesmo uma espécie de band-aid frente às paisagens fragmentadas e contrastantes que compõem o cenário nacional. Dessa forma, a adoção de uma estética naturalista na TV brasileira pode ser vista como articulada a um projeto nacional-popular que viabilizou e orientou a constituição do sistema de comunicação no Brasil ${ }^{5}$.No panorama histórico do início do século XXI, porém, o projeto nacional-popular que constitui a tevê no Brasil está mais que consolidado.

Hoje em dia, tanto essa epistemologia quando noções que sustentaram esses realismos/naturalismos, como "identidade nacional", por exemplo, estão "fraturadas" por forças externas e internas. É de se perguntar, então, a que serve, a que responde a permanência dessa ideologia estética, confirmada tanto pelo diversidade de produtos postos em circulação pelas redes de tv quanto pela forma do debate que suscitam. Afinal, novelas, telejornais, minisséries e outros programas se apresentam e mesmo se legitimam frente aos espectadores como "rea- 
lidade", ofertando-se à crítica em termos de fidelidade/ infidelidade, parcialidade/imparcialidade; falso/verdadeiro.

\section{O telejornal e seus espectadores}

No caso do telejornal, essa pergunta fica mais complexa quando se observa a própria evolução do meio, da "paleo" para a "neo" televisão. Termos cunhados por Eco (1984) e depois desenvolvidos por Casseti e Odin(1990), "paleo" e "neo" televisão corresponderiam a momentos históricos separados e a modos distintos da relação mundo/tv/espectador. Num primeiro momento, a tv seria "hierárquica" em relação ao espectador, ao qual teria que informar e educar. Assim, a paleotv seria "uma janela para o mundo", em que cada programa, bem inserido na grade de programação, teria não só uma lógica própria, mas proporia um contrato comunicacional específico. A neotevê, por sua vez, segundo Eco(1984), substitui a verdade do enunciado, ou seja, "a aderência entre o enunciado e o fato", pela verdade da enunciação. A neotevê diz menos do exterior e muito mais do mundo criado na interação com o espectador. Ao invés de uma grade de programação, um fluxo intenso em que programas se misturam e se indistinguem em seu caráter ficcional, informativo ou lúdico. Como afirmam Cassetti e Odin(1990), a neotevê substitui um funcionamento em termos de contrato por um outro, menos referencial e predominantemente fático, voltado para o contato com o espectador.

Nesse contato, os apresentadores e espectadores convidados que aparecem no vídeo funcionam como espécies de alter ego do espectador que está em casa, com os quais este identifica e se relaciona. Assim, menos que uma relação em três (mundo/video/espectador) a neotevê cria uma aparente relação binária eu/você. Mais ainda, como formula Eco, a neo tevê "...procura entreter o espectador dizendo-lhe 'eu estou aqui, eu sou eu e eu sou vocế"' (1984, p.183). A mudança da paleo para a neo $t v$, Eco deixa entrever, sugere uma mudança estética forte em todo o meio. Se a paleotv funda-se na "colagem" entre enunciado e referente, ela se apresenta como marcada pelo realismo e pelo esforço da constituir a teve como um "meio" de transmitir/refletir o mundo. Daí, inclusive sua relação hierárquica, pedagógica, informativa com seu espectador. A "neotevê" por sua vez substitui a referencialidade pelo contato, instituindo-se como espaço fático, de jogo. Uma estética lúdica (JOST, 2004; CANNITO,2007)se faz presente, não apenas sob a égide do entretenimento e dos programas de auditório, mas certamente na submissão de antigas diferenças, como entre programas ficcionais e informativos. Para o jogo, nada mais importante que o contato. Afinal, um jogo não tem "fim": joga-se pelo prazer do próprio jogar.

Ainda que bastante difundida e aceita, a distinção entre paleo/neo tevê traz a pergunta se haveria tal cisão radical entre uma e outra, se a paleo está mesmo no passado ou se ainda há resquícios na tevê de hoje. Mesmo porque, é importante lembrar, como aponta Robert Allen (2007) que o meio é algo em constante transformação e o que entendemos por tevê nos anos 80 não é o que entendemos hoje, uma realidade histórica por sua vez em vias de desaparecer. No que tange ao telejornal, a princípio poderia haver uma aparente contradição entre seus presumidos valores jornalísticos e sua existência como neotevê. Afinal, o telejornal se justifica por seus compromissos com a verdade e a realidade.

Ao analisar os telejornais franceses, Verón (2001) observa que os apresentadores surgem no vídeo menos como "donos da verdade", mas como uma espécie de representante do espectador. "Ele é como eu", é a máxima cunhada por Verón para designar a identidade entre apresentador e espectador. Com isso, constitui-se uma espécie de relação de contiguidade em que o espaço doméstico continua no vídeo e vice-versa, o que permitiria ver "de que real se fala: uma tela de tevê". Ou como alerta Robert Stam:

A televisão, se não é recebida criticamente, engendra uma espécie de confusão de pronomes: entre o 'Eu' espectador e o 'Ele', ou 'Ela', apresentador, vistos como empenhados em um diálogo mutuamente lisonjeiro. Esse 'Nós' ficctício pode, assim, falar com entusiasmo de 'nós' e com frieza de seja quem for colocado na posição do 'Eles' $(1985$, p.86)

Há portanto um "Nós" televisivo que parece definir o circuito comunicativo que vincula telejornal e seus espectadores. Esse "nó" não fala simplesmente de um outro mundo, mas traz notícias do mundo em que vivemos e cuja autenticidade é regulada predominantemente pela legitimidade reconhecida pelo espectador. Assim, se o telejornal traz um mundo, ele necessita que esse "real" seja autenticado pelas pessoas em suas casas. Para tal, o telejornal certamente mobiliza tanto recursos da "neo" quanto da "paleo"tevê. Não há como o telejornal abrir mão da verdade da enunciação, ou seja, do contato, da busca da identidade com um modo de dizer da tevê, incorporada nos seus rituais narrativos, nos apresentadores e repórteres. Também não há como o telejornal abrir mão do discurso de honestidade, de compromisso com a "verdade", com os fatos. Afinal, como observa Charaudeau (2006), “...o gênero telejornal, sob a proposta de nos apresentar os acontecimentos que surgem no mundo referencial, nada mais faz do que nos entregar (já pronto) um mundo evenemencial construído por ele mesmo e em parcelas.". Com isso, diz ele, "[e]ncontramo-nos, então, em plena ilusão de realismo e em pleno simulacro de verdade, mas é através desse 'fazer crer' que o telejornal se define" (2006,p.230)

Dessa forma, o "Nós" telejornalístico se ancora tanto no contato quanto no discurso ideológico-estético realista/naturalista. No entanto, essa afirmação merece ser 
vista com calma, pois acena não com a justaposição de elementos heterogêneos, mas com uma relação de complementariedade. O contato telejornalístico teria como um dos seus elementos o contrato informativo, de caráter realista / naturalista. Essa fusão seria encontrada tanto nos rituais narrativos, no "olho no olho" dos âncoras e repórteres, na constituição, enfim, de uma espaço contínuo entre o vídeo e o lar, quanto no discurso da função jornalística e no uso de recursos que trabalhariam para a produção da ilusão referencial.

É importante observar que realismo aqui é visto tanto como um discurso, portanto ideológico, quanto como um certo uso de certos procedimentos. É exatamente nessa dimensão "menor", do uso de recursos narrativos em notícias e reportagens é que a fusão acima pode ser facilmente reconhecida. Conforme discutido em outro artigo (LEAL,2006), o papel da imagem num telejornal pode variar de uma função estreitamente referencial a até mesmo escapar de qualquer "iconicidade estrita", atuando então na captação e manutenção da atenção do espectador. Da mesma forma, a dependência do telejornal da linguagem verbal, menos que pobreza, faz ver as diferentes funções de cada linguagem. Se a imagem pode variar de papel, a palavra quase sempre mantém-se sob o cânone rígido do realismo, um uso só quebrado quando serve ao contato.

Não há, portanto, a contradição apontada por Stam entre recursos naturalistas e de distanciamento. A exposição da sala de redação, dos microfones e da parafernália de gravação, menos que rechaço, servem à construção da proximidade com o espectador e à própria ilusão referencial. Ao mesmo tempo em que desmitificam o "aparelho de base", tornando-o familiar ao espectador, contribuem para autenticidade da narrativa do real, na repetição da operação identificada por Sussekind nos anos 70: onde se lê jornal, leia-se país; onde se lê jornalista, leia-se sociedade brasileira, todos nós. Com isso, o telejornal reforça sua identidade com o espectador: ele é como eu e nós estamos num mesmo mundo.

A relação de complementariedade entre contato/realismo se constitui como uma resposta ao dito excesso de informações contemporâneo. Se, nos anos 70, como Sussekind observou, a retomada naturalista nos romancesreportagem foi justificada pelo controle da informação exercido pelo regime militar, hoje em dia vive-se a situação oposta. A tevê dos anos 1990 em diante não é mais apenas a tevê das quatro ou cinco grandes redes nacionais, mas também as diversas tevês via satélite, via cabo e os canais locais. Constituída após o controle remoto e a popularização do zapping, essa nova tevê - já em transformação com emergência das tecnologias digitais - exige ancoragens mais elaboradas e eficazes contra a dispersão e indiferença do espectador. Da mesma forma, tanto a "realidade" quanto a "identidade" nacional, se fraturadas, surgem como desafios insuperáveis. Seria possível um band-aid agora?
Arlindo Machado (2000), ao levar a tevê a sério, sugere uma possível resposta ao observa que o telejornal, ao buscar registrar o que está acontecendo, realiza "...uma colagem e depoimentos e fontes numa sequência sintagmática", mas que não chega a constituir um "discurso suficientemente unitário, lógico ou organizado a ponto de poder ser considerado 'legível' como alguma coisa 'verdadeira' ou 'falsa' (2000,p.110). Assim, para ele, não há uma "entidade narradora central" no telejornal que daria coerência e sentido às notícias postas em sequência. Se assim o for, o Brasil que se vê na tevê de hoje, então, é bem pouco coeso. Na ausência de um projeto nacional majoritário, que unificaria realidades e contradições, o telejornal necessita mais e mais do espectador, âncora e elemento articulador das notícias. Não se trata, então, de reconhecer no telejornal nacional todo o país, mas um Brasil, aquele no qual nós habitamos, aquele que temos como referência. O discurso e o uso de recursos sob a égide realista/naturalista apresentam-se como formas de autenticação da realidade televisiva, cada vez mais uma, entre outras. Não se trata mais, portanto, da tevê como janela de um outro mundo e de um telejornal estritamente informativo e realista. Telejornal hoje é também ritual e diversão e o real que oferece é aquele que ele quer que nós tenhamos como nosso. Mais ainda, que tenhamos como nossa realidade preferencial, referência e parâmetro para todas as outras mamecos

\section{NOTAS}

* Versão revisada de trabalho apresentado no Grupo de Trabalho "Estéticas da Comunicação", do XVII Encontro da Compós, na UNIP, São Paulo, SP, em junho de 2008.

1. A edição brasileira utilizada neste artigo é a $9^{a}$, de 2003.

2. Eco não fornece muitos elementos para o entendimento da expressão. Ao tecer suas considerações sobre a neotevê, porém, como veremos à frente, Eco traz pistas de que entende o conceito de mímesis próximo ao de Iser (1983), que afirma que a noção de um real a ser representado é dependente da compreensão de uma "ordem fechada do mundo", de uma realidade estável. Nas sociedades contemporâneas, pós-modernas talvez, as estabilidades do mundo, do real, ficam cada vez mais frágeis e, com isso, para Iser, só épossível pensar em mímesis como performance, ou seja, como uma referente que instaura na e para relação do receptor.

3. sobre o realismo na Brasil, ver, entre outros, Lima (1986 e 1984).

4. Nicoli Tassis observou o mesmo movimento nos li- 
vros-reportagens publicados no Brasil nos anos 90, vistos como continuadores dos romances-reportagem.

5. Sobre a constituição do sistema de comunicação brasileiro e seu projeto nacional ver, entre outros, Ortiz $(1985,1988$ e 2003) e Castro (1997)

\section{REFERÊNCIAS}

ALLEN, Robert C. Reflexões sobre estudos de televisão do meu local de observação. Cadernos de Televisão. Rio de Janeiro: Instituto de Estudos da Televisão, $n^{\circ}$ 01, julho de 2007, p.8-22;

CANNITO, Newton. Potenciais da linguagem da Tv digital. Cadernos de Televisão. Rio de Janeiro: Instituto de Estudos da Televisão, nº 01, julho de 2007, p.8392;

CASTRO, M.C. Na tessitura da cena, a vida. Belo Horizonte:Ed.UFMG, 1997

CASSETTI, Federico; ODIN, Roger. De la paléo- à la néotélévision.Communications. Paris: EHESS, n.51, 1990,p.09-26;

ECO, Umberto. Obra aberta. $9^{a}$ ed. São Paulo: Perspectiva, 2003

ECO, Umberto. Viagem na irrealidade cotidiana.Rio de Janeiro: Nova Fronteira, 1984;

FAHLE, Oliver. Estética da televisão. GUIMARÃES,C;LEAL;B;MENDONÇA, C(org.) Comunicação e experiência estética. Belo Horizonte: Ed. UFMG, 2006, p. 190-208;

GUMBRECHT, Hans. Production of presence. Stanford: Stanford University Press, 2004

ISER, Wolfgang. Towards a literary anthopology. Londres: John Hopkins University Press, 1993

LEAL, Bruno S. Reflexões sobre a imagem: um estudo de caso. Revista E-compós,nº, abril de 2006;

LIMA, L.C. O controle do imaginário. São Paulo: Brasiliense, 1984

LIMA,L.C.Sociedade e discurso ficcional. Rio de Janeiro: Guanabara, 1986

JOST, François. Seis lições sobre a televisão. Porto Alegre:Sulina, 2004
ORTIZ, R.Moderna tradição brasileira. São Paulo: Brasiliense, 1988

ORTIZ, R. Cultura brasileira e identidade nacional. São Paulo: Brasiliense, 1985

ORTIZ, R. Mundialização e cultura. São Paulo: Brasiliense, 2003

PONTE, Cristina. Para entender as notícias. Florianópolis: Insular, 2005;

PUCCI JR, Renato. Anomalias teóricas na concepção modernista da televisão brasileira. Revista Fronteiras. Porto Alegre: Unisinos, setembro/dezembro 2005, p. $185-194$

STAM, Robert.O telejornal e seu espectador. Novos Estudos Cebrap. São Paulo: Cebrap, nº 13, outubro de 1985, p.74-87

SUSSEKIND, Flora. Tal Brasil, qual romance. Rio de Janeiro: Achiamé, 1984;

TASSIS, N. Nos rastros de Abusados e Rota 66.2006, $150 f$. Dissertação (Mestrado em Comunicação). Universidade Federal de Minas Gerais, Belo Horizonte.

VERÓN, E. El cuerpo de las imágenes. Bogotá: Norma Editorial, 2001.

WOLFE, Tom. Radical Chique e o novo jornalismo. São Paulo: Cia das Letras, 2005. 